Jurnal Onoma: Pendidikan, Bahasa dan Sastra

ISSN 2443-3667

PBSI FKIP Universitas Cokroaminoto Palopo

ISSN 2715-4564

(Print)

Volume 7 Nomor 1 Tahun 2021

\title{
Struktur Bahasa pada Toponimi Jalan di Kota Bengkulu
}

\author{
Eli Rustinar 1, Reni Kusmiarti ${ }^{2}$ \\ Universitas Muhammadiyah Bengkulu ${ }^{1,2}$ - Indonesia \\ elirustinar@umb.ac.id 1, renikusmiarti@umb.ac.id²
}

\begin{abstract}
Abstrak
Toponimi atau penamaan (naming) menarik dikaji dari sisi linguistik dan budaya karena dengan adanya toponimi misal toponimi suatu tempat dapat menghasilkan cerita sejarah penamaan karena suatu nama tempat dari suatu budaya akan menghasilkan cerita dan sejarah masa lampau dan mengandung lapisan makna. Berlandaskan hipotesis Sapir-Worf bahwa penggunaan bahasa mempengaruhi cara seseorang berpikir dan berperilaku yang salah satunya pada penggunaan struktur bahasa karena dari struktur bahasa yang digunakan terus menerus dapat mempengaruhi cara seseorang berpikir dan berperilaku sehingga akan ditemukan cara pandang dan budaya masyarakat setempat. Tujuan penelitian adalah diperolehnya deskripsi struktur bahasa toponimi jalan di Kota Bengkulu. Metode penelitian deskirptif. Data dan sumber data bersumber dari dokumentasi hasil penelitian toponimi nama-nama jalan di Kota Bengkulu. Teknik pengumpulan data menggunakan teknik catat dan introspeksi. Analisis data menggunakan teknik pilah. Hasil penelitian adalah terdapat tujuh belas toponimi nama jalan di kota Bengkulu, struktur bahasa yang digunakan berbentuk kata dan majemuk dengan kecenderungan menggunakan kata majemuk.

Kata kunci: Toponimi Jalan, Struktur bahasa, Kota Bengkulu
\end{abstract}

\section{Pendahuluan}

Toponimi atau penamaan (naming) suatu daerah memiliki makna dibalik nama satu tempat. Di dalam penamaan terdapat nilai-nilai kehidupan atau filosofis yang menjadi ciri khas bahasa dan masyarakat daerah. Penamaan tempat ternyata tidak pernah lepas dari berbagai aspek atau berbagai fenomena geografis yang hadir di balik nama tempat itu, karena pemberian nama tempat biasanya berdasarkan pengalaman dan pertimbangan dari masyarakat sendiri.

Hasil Disertasi Rustinar (2020: 261) mengenai Makian Bahasa Melayu Bengkulu: Kajian Sosiopragmatik terdapat data nama lokasi penelitian yaitu: Teluk Segara, Selebar, Ratu Samban, Malabero, Bajak, Tengah Padang, Kampung Bali, Sumur Meleleh, Pagar Dewa, dan Belakang Pondok seperti pada gambar 1 berikut. 


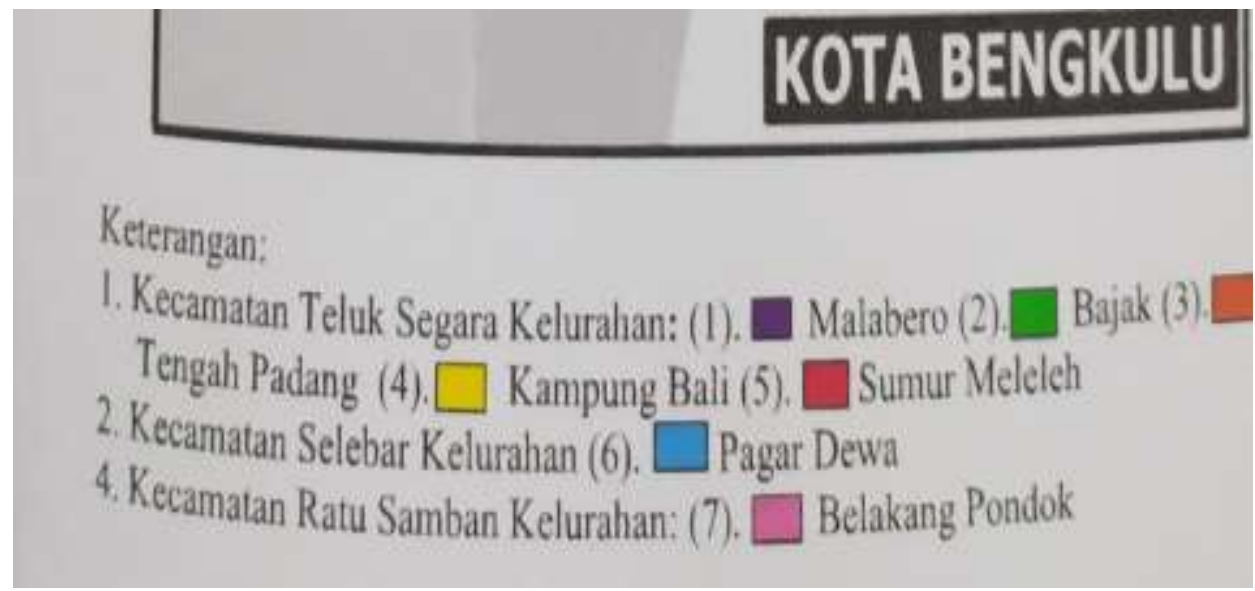

Gambar 1. Nama Lokasi Penelitian Terdahulu Disertasi Rustinar (2020)

Ditemukan nama diri (Ratu Samban), arah (Belakang Pondok), ukuran (Selebar), tempat (arah, titik) di antara dua tepi atau batas (Tengah Padang), atau pekerjaan tidak baik (Bajak) dan pada kajian linguistik nama-nama tersebut disebut dengan konsep sebagai penamaan atau toponimi (naming). Hasil pengamatan lapangan di Kota Bengkulu juga terdapat penamaan jalan, yaitu: nama jalan Sungai Rupat dan nama jalan Mahakam Raya pada plang jalan atau papan nama seperti gambar 2 berikut.

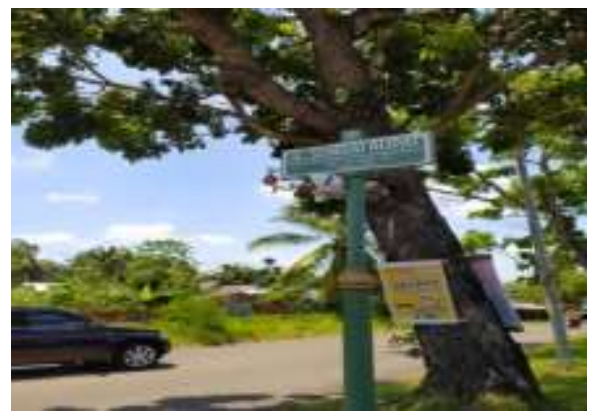

Plang nama jalan Sungai Rupat

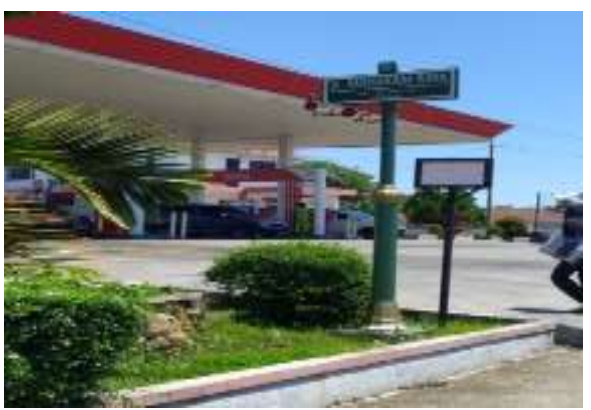

Plang nama jalan Mahakam Raya

Kesemua penamaan kecamatan, kelurahan, dan nama jalan jika menggunakan satuan analisis linguistik sebagai struktur bentuk yaitu: Teluk Segara, Selebar, Ratu Samban, Malabero, Bajak, Tengah Padang, Kampung Bali, Sumur Meleleh, Pagar Dewa, dan Belakang Pondok adalah struktur bentuk yang disebut sebagai kata dan kata majemuk dengan kecenderungan menggunakan kata majemuk yang tampak pada tabel identifikasi berikut.

Tabel 1. Contoh Analisis Struktur Bahasa Data Penelitian Terdahulu

\begin{tabular}{|l|l|l|}
\hline Nomor & \multicolumn{1}{|c|}{ Struktur Bentuk } & \multicolumn{1}{|c|}{ Data } \\
\hline \multirow{2}{*}{1} & Kata Majemuk & Teluk Segara \\
\cline { 3 - 3 } & & Ratu Samban \\
& & Tengah Padang \\
& & Kampung Bali \\
& & Sumur Meleleh \\
\hline
\end{tabular}




\begin{tabular}{|l|l|l|}
\hline & & Pagar Dewa \\
\cline { 3 - 3 } & & Belakang Pondok \\
\hline 2 & \multirow{2}{*}{ Kata } & Selebar \\
& & Malabero \\
& & Bajak \\
\hline
\end{tabular}

Alasan penamaan suatu tempat dapat disebabkan hasil dari proses-proses alam, hasil rekayasa, atau didasarkan pada gagasan, harapan, cita-cita, dan citra rasa masyarakat terhadap tempat tersebut agar sesuai dengan apa yang dikehendaki dan memiliki cabang ilmu yang menyelidiki nama tempat, Termasuk lokasi desa, dan kota yang memiliki keterkaitan antara bahasa, budaya, dan pikiran dengan merujuk pada hipotesis Sapir-Worf bahwa penggunaan bahasa mempengaruhi cara seseorang berpikir dan berperilaku begitu juga penggunaan struktur bahasa, suatu yang digunakan secara terus menerus akan mempengaruhi cara seseorang berpikir dan berperilaku.

Berdasarkan latar belakang dan rumusan masalah, maka penelitian ini bertujuan untuk mendeskripsikan struktur atau bentuk bahasa toponimi jalan di Kota Bengkulu. Pada ruang lingkup lebih luas penelitian ini memiliki manfaat untuk mengidentifikasi nama jalan, menemukan makna dan sejarah nama jalan, dan mengidentifikasi apa saja nilai-nilai budaya yang terkandung dalam penamaan jalan di Kota Bengkulu, dan dapat menjadi materi bahan ajar muatan lokal

\section{Kerangka Teori Toponimi}

Secara harafiah toponimi (naming) berarti nama tempat. Dalam teori linguistik, toponimi dapat dilihat sebagai 'tanda' yang terjadi tidak secara arbitrer. Kita mencintai dan memedulikan suatu nama tertentu karena nama tersebut mengandung lapisan makna. Lapisan makna tersebut berasal dari budaya tempat berada dan melampaui kata-kata sehari-hari atau biasa. Pada ilmu semantik, kajian toponimi merupakan bagian dari semantik leksikal hubungan antara nama dan pengertian sehingga jika seseorang membayangkan suatu benda ia akan segera mengatakan benda itu sebagai hubungan timbal balik antara bunyi dan pengertian.

Terjadinya perubahan makna disebabkan adanya asosiasi pengguna bahasa terhadap sesuatu. Faktor yang menyebabkan perubahan makna menurut Ullman (2012:251-262) adalah a). Kebahasaan yang berhubungan dengan fonologi, morfologi, dan sintaksis; b). Kesejarahan (historical causes) berhubungan dengan perkembangan kata yang dapat terjadi karena faktor objek, institusi, ide, atau konsep ilmiah; c). Sosial (social caucses) disebabkan hubungan perkembangan kata dalam masyarakat; d) Psikologis (psicological causes) adalah perubahan makna yang dapat disebabkan emotif (emotive factor) atau tabu (taboo); e). Pengaruh bahasa asing adalah perubahan bahasa yang satu terhadap bahasa yang lain dan tidak dapat dihindarkan karena perkembangan zaman; dan f). Faktor kebutuhan kata baru, adalah perubahan makna karena kebutuhan pengguna bahasa yang mengalami perkembangan sebagai alat komunikasi. 
Nama tempat merupakan suatu bentuk cerita dan sejarah yang secara tradisi diturunkan menelusuri proses penamaan (naming) berbagai hal, seperti jalan, orang, makanan, buah-buahan, tumbuh-tumbuhan, dan tempat. Menurut Ullman (2012: 92) "Toponimi adalah cabang onomastik sebagai studi tentang nama-nama tempat" yang menunjukkan bahwa penyelidikan tentang asal usul nama tempat merupakan salah satu cabang ilmu kebumian yang mengkaji dan mempelajari permasalahan penamaan unsur geografi baik alami maupun buatan manusia.

Selain mempelajari masalah nama, ilmu ini juga mengkaji pembakuan penulisan, ejaan pengucapan (fonetik), sejarah penamaan, serta korelasi nama dengan kondisi alam atau sumber daya yang dimiliki sebuah unsur geografi. Toponimi memiliki hubungan erat dengan kondisi fisik geografis, masyarakat yang menghuninya, dan kebudayaan yang tumbuh di wilayah tersebut. Ikhwal nama maknanya sangat luas, tidak hanya secara fisik seperti kondisi lokasi geografisnya saja, juga meliputi asal usul, kondisi, dan sosial budaya, serta agama masyarakatnya, nilai-nilai yang terkandung di dalam sistem budaya yang dimiliki. Sistem penamaan tempat adalah tata cara atau aturan memberikan nama tempat pada waktu tertentu yang dapat menunjukkan kealamian suatu lokasi.

Alasan penamaan suatu tempat dapat disebabkan hasil dari proses-proses alam, hasil rekayasa, atau didasarkan pada gagasan, harapan, cita-cita, dan citra rasa masyarakat terhadap tempat tersebut agar sesuai dengan apa yang dikehendaki dan memiliki cabang ilmu yang menyelidiki nama tempat, termasuk lokasi desa, dan kota yang memiliki keterkaitan antara bahasa, budaya, dan pikiran dengan merujuk pada hipotesis Sapir-Worf bahwa penggunaan bahasa mempengaruhi cara seseorang berpikir dan berperilaku begitu juga penggunaan struktur bahasa, suatu yang digunakan secara terus menerus akan mempengaruhi cara seseorang berpikir dan berperilaku.

Pada penelitian yang dilakukan Munir (2017) mengenai Jejak Indonesia dalam Penamaan Nama Tempat dan Jalan di Singapura: Sebuah Kajian Toponimi menunjukkan betapa pentingnya penelitian toponimi menunjukkan bahwa sejarah penamaan beberapa nama tempat di Negara Singapura tidak dapat dilepaskan dari pengaruh bangsa Indonesia. Pengaruh ini dapat dilihat dari penamaan nama-nama tempat dan jalan termasuk Suku Bugis yang berasal dari Indonesia memberikan jejak yang cukup signifikan pada penaman tempat seperti “Kampung Bugis' dan distrik "Sengkang' yang saat ini sangat dikenal oleh kawasan wisatawan. Hasil penelitian jugga menunjukkan bahwa penamaan nama jalan dan tempat yang dipengaruhi oleh sejarah Indonesia di Negeri Singa juga berasal dari namanama kota, nama-nama buah-buahan, nama-nama tempat, dan nama-nama bunga.

Nama adalah kata untuk menyebut atau memanggil orang (tempat, barang, dan binatang). Nama merupakan doa, cita-cita, dan harapan dari orang tuanya. Nama yang diberikan kepada seseorang mempunyai arti yang sangat penting dalam kehidupannya. Nama adalah kata untuk menyatakan panggilan atau sebutan orang, barang, tempat, dan lain sebagainya. Jenis penamaan dapat disebabkan peniruan bunyi, penyebutan bagian, penyebutan sifat khas, penemu dan pembuat, tempat asal, bahan, keserupaan, pemendekan, penamaan baru, pengistilahan, atau pendefinisian. 
Penamaan pada nama diri dapat bermakna bermacam-macam, dapat sebagai:

a) Nama yang bermakna bunga dan indah. Nama adalah nama yang mempunyai makna bunga dan indah adalah nama yang komponen katanya mengandung makna bunga dan keindahan. Nama yang mengandung keindahan seperti emas, binatang, cahaya, dan mutiara dan biasanya ditandai dengan adanya komponen kata seperti ratna (intan), puspa (bunga), cahaya (sinar), dan ayu (cantik);

b) Nama yang bermakna selamat adalah nama yang komponen kata sebagai pembentukan nama itu mengandung makna keselamatan, artinya terpelihara dari bencana, terhindar dari bahaya, mana sentosa, sejahtera tidak kurang suatu apapun, sehat, tidak mendapat gangguan kerusakan, beruntung, tercapai maksudnya;

c) Nama yang bermakna sifat baik adalah elok, patutu, teratur, apik, rapi, beres, tidak ada celanya. Nama yang mempunyai sifat baik adalah nama yang komponen kata sebagai pembentukan nama tersebut, mengandung makna sifat baik seorang manusia. Sifat baik dari manusia ini antara lain bijaksana, kokoh dalam pendirian dan rajin. Nama baik ini biasanya ditandai dengan komponen-komponen kata yang bermakna baik, misalnya satria 'luhur dalam budi';

d) Nama yang mempunyai makna keadaan dan situasi, adalah nama yang mempunyai makna keadaan dan situasi adalah nama yang komponen kata sebagai pembentukan nama tersebut menunjukkan keadaan atau situasi saat dilahirkan. Komponen kata bentuk nama yang bermakna keadaan dan situasi misal purnama karena dilahirkan saat purnama, prihatin karena dilahirkan saat keadaan keluarga memprihatinkan;

e) Nama yang mempunyai makna peristiwa, adalah nama yang diberikan kepada seseorang untuk mengenang peristiwa yang terjadi ketika kelahiran, peristiwa adalah kejadian, hal, perkara. Komponen kata yang menandai nama yang bermakna peristiwa antara lain huru hara karena dilahirkan bersamaan dengan peristiwa huru-hara. Peristiwa yang bersamaan yaitu peristiwa dalam arti yang luas. Peristiwa keadaan yang menimpa bayi atau keluarga yang bersangkutan;

f) Nama yang diambil dari nama tokoh, adalah nama yang diberikan oleh orang tua kepada anaknya karena ada rasa kagum terhadap sang tokoh dengan harapan anak bisa memiliki sifat yang terpuji seperti sifat yang dimiliki oleh sang tokoh, misalnya nama Muhammad, yaitu Nabi yang mempunyai sifat terpuji;

g) Nama yang bermakna urutan, adalah nama yang bermakna urutan kelahiran dalam lingkungan saudara kandung atau dengan kata lain urutan kelahiran itu menyatakan anak ke berapa dalam keluarga, misal eka berarti satu, $d w i$ bermakna dua;

h) Nama yang bermakna waktu kelahiran, adalah nama seseorang yang didasarkan kepada waktu kelahirannya, yang ditentukan oleh nama hari kelahiran yang dilahirkan saat kelahiran, misalnya rebo nama lain untuk hari Rabu;

i) Nama yang bermakna singkatan, adalah nama yang terdiri dari singkatan nama ayahibu. Komponen kata yang digunakan biasanya singkatan dari kedua orang tua dengan maksud agar selalu bersatu, misalnya Wika adalah singkatan dari dua kata, yaitu Willy dan Kartini 
Jurnal Onoma: Pendidikan, Bahasa dan Sastra

ISSN 2443-3667 (Print)

PBSI FKIP Universitas Cokroaminoto Palopo

ISSN 2715-4564 (Online

Volume 7 Nomor 1 Tahun 2021

\section{Antropologi Linguistik}

Ilmu yang mengkaji hubungan antara bahasa dan budaya dinamakan antropologi linguistik. Pendekatan antropolinguistik berusaha mencermati apa yang dilakukan orang dengan bahasa dan ujaran-ujaran yang diproduksi, gesture yang dihubungkan dengan konteks pemunculannya yang secara filosofi adalah menganalisis cara berpikir melalui strukur bahasa. Analisis terhadap kosakata suatu bahasa sangat penting untuk menguak lingkungan fisik dan sosial di mana penutur suatu bahasa bermukim. Analisis masalah kebahasaan suatu masyarakat merupakan fenomena budaya, yang dapat dipakai sebagai pemahaman suatu budaya.

Istilah antropologi linguistik (lingistik antropologi) berpaham pada Duranti (1997) adalah sebagai studi tentang bahasa sebagai suatu sumber budaya dan tuturan sebagai kebiasaan atau praktik budaya yang lebih jauh mengupas bahasa untuk menemukan pemahaman budaya berkaitan dengan hipotesis "Sapir-Whorf". Hipotesisis "Sapir-Whorf" sebagai relativisme bahasa hipotesis bahwa bahasa manusia mempengaruhi lingkungan dalam memproses dan membuat kategori-kategori realitas di sekitarnya.

\section{Morfologi}

Morfologi menurut Djajasudarma (2016a: 32) adalah ilmu yang mempelajari morfem, dan morfem adalah unsur bahasa yang mempunyai makna dan ikut mendukung makna. Unsur bahasa yang mempunyai makna disebut morfem bebas, berdiri sendiri dalam arti memiliki makna atau acuan, sementara itu, unsur yang ikut mendukung makna disebut morfem terikat adalah morfem yang tidak dapat berdiri sendiri, hanya dapat meleburkan diri pada morfem yang lain. Dalam tinjauan morfologi yang digunakan dalam penelitian ini memfokuskan pada proses morfologis yang mengakibatkan perubahan bentuk pada kata dengan menghubungkan morfem yang satu dengan morfem yang lain, yaitu kata majemuk.

Menurut Verhaar (2006: 155) kata majemuk adalah proses morfemis yang menggabungkan dua morfem dasar menjadi satu kata, dengan contoh daya juang. Konsep tersebut menjelaskan bahwa kata majemuk tidak memungkinkan terpisahnya daya dan juang karena bentuk daya saya juang adalah tidak gramatikal.

Pandangan Djajasudarma (2016c: 47 - 48) lebih rinci lagi bahwa, kata majemuk merupakan gabungan dua unsur yang masing-masing memiliki makna, tetapi hasil gabungannya memiliki makna tersendiri (kambing hitam, mata-mata). Kriteria sebuah kata majemuk, yaitu: 1) dari ciri semantik sebuah kata majemuk memiliki satu makna, 2) dari ciri fonologis sebuah kata majemuk memiliki satu tekanan, dan 3) dari ciri struktur sebuah kata majemuk merupakan gabungan dua unsur/kata.

Berdasarkan teori, contoh, dan penjelasan tersebut, maka penentuan makian bentuk kata majemuk bahasa Melayu Bengkulu adalah: (a) merupakan gabungan dua unsur/kata, (b) gabungan tersebut memiliki satu makna (c) gabungan unsur tersebut bersifat padat, bila dipisahkan atau disisispi unsur lain menjadi tidak gramatikal, (d) Komponen unsur tidak dapat dipertukarkan. 
Jurnal Onoma: Pendidikan, Bahasa dan Sastra

ISSN 2443-3667 (Print)

PBSI FKIP Universitas Cokroaminoto Palopo

ISSN 2715-4564 (Online

Volume 7 Nomor 1 Tahun 2021

\section{Metode}

Metode merupakan cara kerja yang teratur, terpikir baik, dan bersistem untuk memudahkan pelaksanaan suatu kegiatan guna mencapai tujuan yang telah ditentukan (Djajasudarma, 2010: 1). Oleh karena itu, pemilihan metode yang tepat dalam suatu kegiatan dapat memaksimalkan pencapaian tujuan. Metode deskriptif dipilih dengan pertimbangan ciri-ciri dan sifat-sifat data sebagaimana adanya yang ditujukan untuk mendeskripsikan fenomena-fenomena yang ada, baik fenomena alamiah maupun fenomena buatan manusia. Metode lapangan (etnografi) digunakan karena peneliti terjun langsung ke masyarakat dengan teknik pengumpulan data utama. Data penelitian adalah nama-nama jalan di Kota Bengkulu dengan sumber penelitian adalah dokumentasi fotofoto nama jalan di Kota Bengkulu dalam bentuk plang jalan yang digunakan. Penyajian hasil data menggunakan instrumen bentuk tabel dengan metode informal karena data yang diperoleh akan disajikan dengan uraian.

\section{Hasil dan Pembahasan}

Berdasarkan Peraturan Pemerintah Ripublik Indonesia No. 34 Tahun 2006 pasal 25 bahwa status jalan secara umum dapat dikelompokkan menjadi lima klasifikasi yaitu: 1). Jalan Nasional, 2). Jalan Provinsi, 3). Jalan Kabupaten, 4). Jalan Kota, dan 5). Jalan Desa. Status jalan ini dapat dilihat penjelasannya menjadi lebih rinci pada pasal 26 sampai dengan pasal 30.

Merujuk pada Peraturan Pemerintah berdasarkan lokasi penelitian, maka nama jalan yang ada di Kota Bengkulu dapat diklasifikasi menjadi jalan nasional, jalan provinsi, dan jalan kota Bengkulu dengan klasifikasi tabel sebagai berikut.

Tabel 2. Nama Jalan di Kota Bengkulu

\begin{tabular}{|c|l|l|l|}
\hline No & \multicolumn{1}{|c|}{ Nama Jalan Kota } & \multicolumn{1}{|c|}{ Nama Jalan Provinsi } & \multicolumn{1}{|c|}{ Nama Jalan Nasional } \\
\hline 1 & Jalan Asahan & Jalan Adam Malik & Jalan Depati Payung Negara \\
\hline 2 & Jalan Bakti Husada & Jalan Ahmad Yani & Jalan Ir. Rustiandi \\
\hline 3 & Jalan Bali & Jalan Beccollen street & Jalan MT. Haryono \\
\hline 4 & Jalan Basuki Rahmat & Jalan Hibrida & Jalan Yos Sudarso \\
\hline 5 & Jalan Batang Hari & Jalan Irian & Jalan RE. Martadinata \\
\hline 6 & Jalan Flamboyan & Jalan Jendral Soedirman & \\
\hline 7 & Jalan Indragiri & Jalan Kalimantan & \\
\hline 8 & Jalan Kebun Veteran & Jalan Raden Patah & \\
\hline 9 & Jalan Raden Patah & Jalan S. Parman & \\
\hline 10 & Jalan. Ratu Agung & Jalan Soeprapto & \\
\hline 11 & Jalan. Soekarno Hatta & Jalan Wisata Pantai Panjang & \\
\hline 12 & Jalan. Sungai Rupat & Jalan Citandui & \\
\hline 13 & Jalan Mahakam Raya & Jalan Hibrida & \\
\hline 14 & Jalan Kapuas & Jalan Jenggalu & \\
\hline 15 & Jalan Fatmawati & Jalan Adam Malik & \\
\hline 16 & Jalan Putri Gading Cempaka & & \\
\hline 17 & Jalan Ratu Agung & & \\
\hline
\end{tabular}


Jurnal Onoma: Pendidikan, Bahasa dan Sastra

ISSN 2443-3667 (Print) PBSI FKIP Universitas Cokroaminoto Palopo

Volume 7 Nomor 1 Tahun 2021

Peraturan Pemerintah Ripublik Indonesis No. 34 tahun 2006 Pasal 29 menjelaskan bahwa yang dimaksud dengan jalan kota adalah jalan umum pada jaringan jalan sekunder di dalam kota. Bila ditafsirkan lebih jauh dapat dijelaskan bahwa jaringan jalan sekunder merupakan sistem jaringan jalan yang menghubungkan antarkawasan di dalam perkotaan yang diatur secara berjenjang sesuai dengan fungsi kawasan yang dihubungkannya. Hal ini menunjukkan bahwa setiap kota memiliki jaringan jalan dalam bentuk penamaan dan batas-batasnya, tetapi batasan pada penelitian ini tidak membahas batas-batas toponimi tetapi hanya pada toponimi atau penamaan (naming) saja. Hasil penelitian toponimi jalan yang ada di Kota Bengkulu dapat dilihat pada tabel di bawah ini.

Tabel 3. Toponimi Nama Jalan Kota Bengkulu

\begin{tabular}{|l|l|}
\hline No. & \multicolumn{1}{|c|}{ Toponimi Nama Jalan Kota Bengkulu } \\
\hline 1 & Asahan \\
\hline 2 & Bakti Husada \\
\hline 3 & Bali \\
\hline 4 & Basuki Rahmat \\
\hline 5 & Batang Hari \\
\hline 6 & Flamboyan \\
\hline 7 & Indragiri \\
\hline 8 & Kebun Veteran \\
\hline 9 & Raden Patah \\
\hline 10 & Ratu Agung \\
\hline 11 & Soekarno Hatta \\
\hline 12 & Sungai Rupat \\
\hline 13 & Mahakam Raya \\
\hline 14 & Kapuas \\
\hline 15 & Fatmawati \\
\hline 16 & Putri Gading Cempaka \\
\hline 17 & Ratu Agung \\
\hline
\end{tabular}

Hasil penelitian tersebut menunjukkan bahwa terdapat tujuh belas plang nama jalan di Kota Bengkulu yaitu: Asahan, Bakti Husada, Bali, Basuki Rahmat, Batang Hari, Flamboyan, Indragiri, Kebun Veteran, Raden Patah, Ratu Agung, Soekarno Hatta, Sungai Rupat, Mahakam Raya, Kapuas, Fatmawati, Putri Gading Cempaka, dan Ratu Agung. Ketujuh belas plang nama jalan di Kota Bengkulu ini dapat dilihat pada gambar di bawah ini. 
Jurnal Onoma: Pendidikan, Bahasa dan Sastra PBSI FKIP Universitas Cokroaminoto Palopo
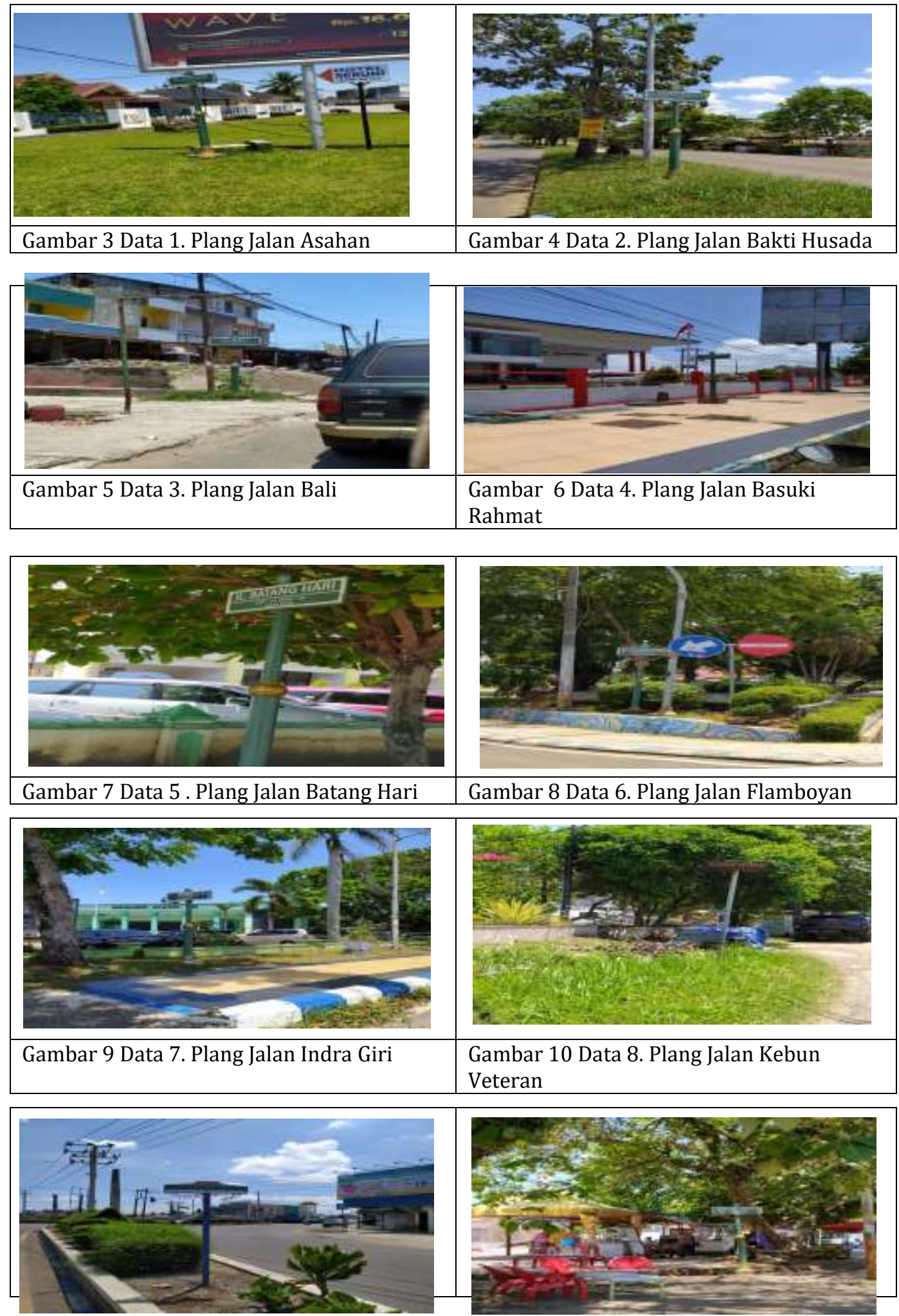

Halaman | 175 
Jurnal Onoma: Pendidikan, Bahasa dan Sastra

ISSN 2443-3667

ISSN 2715-4564

(Print)

PBSI FKIP Universitas Cokroaminoto Palopo

(Online

Volume 7 Nomor 1 Tahun 2021
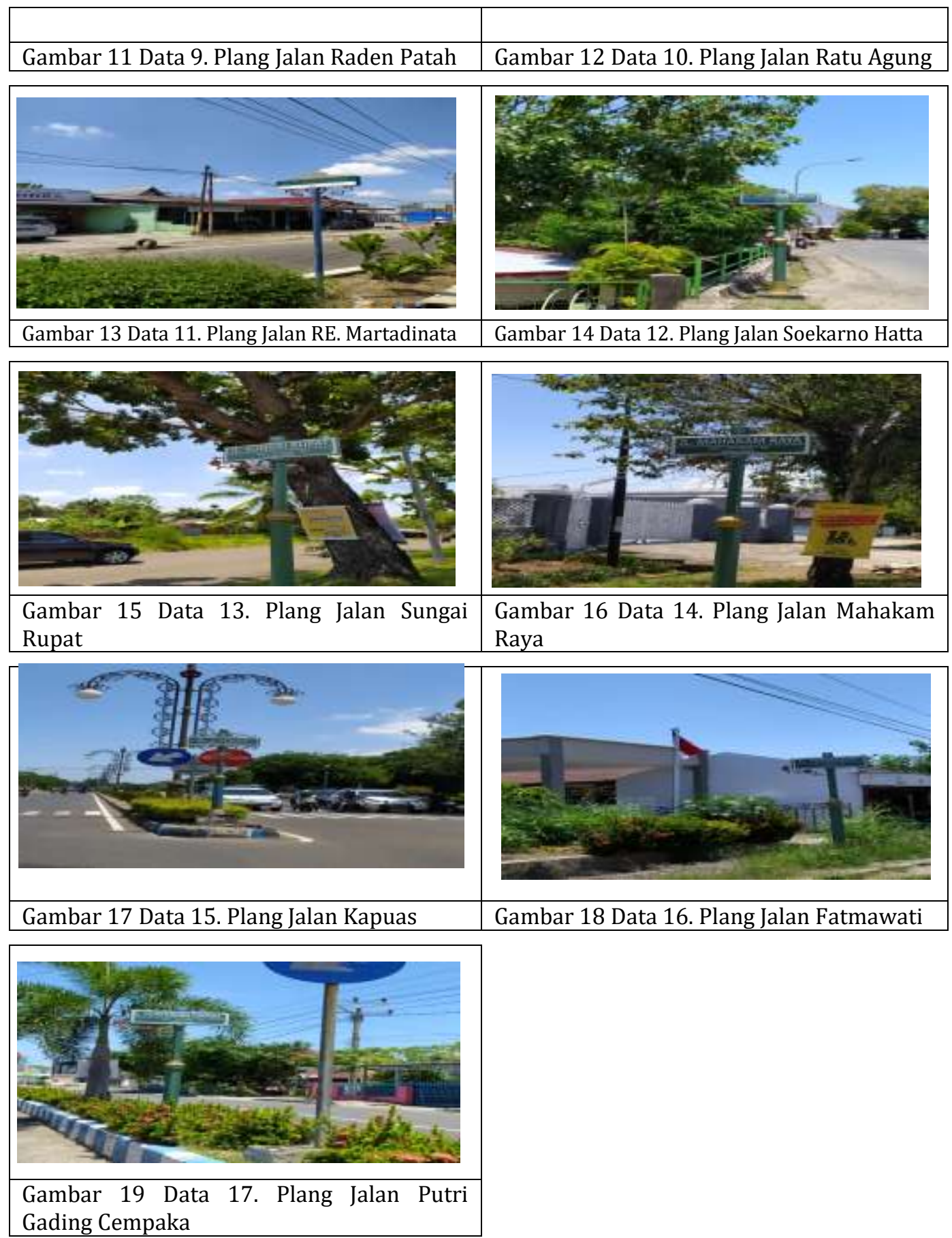

\section{Struktur Bentuk Bahasa Toponimi Jalan Kota Bengkulu}

Hasil dari tujuh belas toponimi jalan Kota Bengkulu bila dianalisis dari struktur bahasa dengan merujuk pada konsep morfem sebagai unsur bahasa yang mempunyai 
Jurnal Onoma: Pendidikan, Bahasa dan Sastra

ISSN 2443-3667 (Print) PBSI FKIP Universitas Cokroaminoto Palopo

Volume 7 Nomor 1 Tahun 2021

makna dan ikut mendukung makna menghasilkan simpulan pada proses morfologis memiliki struktur morfem yang bebas dan morfem yang terikat. Pada proses morfem yang bebas disebut memiliki wujud sebagai kata sedangkan pada proses morfem yang terikat merupakan proses morfologis sebagai afiksasi, majemuk, dan perulangan. Hasil analisis data menunjukkan bahwa struktur bahasa toponimi (naming) pada nama jalan Kota Bengkulu terbagi dua, yaitu: 1. Kata, 2. Majemuk. Keseluruhan hasil klasifikasi penelitian terlihat pada tabel berikut.

Tabel 4. Klasifikasi Struktur Bahasa Toponimi Jalan Kota Bengkulu

\begin{tabular}{|l|l|c|c|}
\hline \multirow{2}{*}{ No. } & Toponimi Nama Jalan & \multicolumn{2}{|c|}{ Struktur/Bentuk Bahasa } \\
\cline { 3 - 4 } & Kota Bengkulu & Kata & Majemuk \\
\hline 1 & Asahan & $\sqrt{ }$ & - \\
\hline 2 & Bakti Husada & - & $\sqrt{ }$ \\
\hline 3 & Bali & $\sqrt{ }$ & - \\
\hline 4 & Basuki Rahmat & - & $\sqrt{ }$ \\
\hline 5 & Batang Hari & - & $\sqrt{ }$ \\
\hline 6 & Flamboyan & $\sqrt{ }$ & - \\
\hline 7 & Indragiri & $\sqrt{ }$ \\
\hline 8 & Kebun Veteran & - & $\sqrt{ }$ \\
\hline 9 & Raden Patah & - & $\sqrt{ }$ \\
\hline 10 & Ratu Agung & - & $\sqrt{ }$ \\
\hline 11 & Soekarno Hatta & - & $\sqrt{ }$ \\
\hline 12 & Sungai Rupat & - & - \\
\hline 13 & Mahakam Raya & - & $\sqrt{ }$ \\
\hline 14 & Kapuas & $\sqrt{ }$ \\
\hline 15 & Fatmawati & $\sqrt{ }$ \\
\hline 16 & Putri Gading Cempaka & - & $\sqrt{ }$ \\
\hline 17 & Ratu Agung & - & \\
\hline
\end{tabular}

\section{Struktur Bahasa Bentuk Kata}

Kata merupakan unsur bahasa yang bebas dan memiliki makna. Ditemukan enam struktur bahasa toponimi nama jalan Kota Bengkulu dalam bentuk kata, yaitu: Asahan, Bali, Indragiri, Flamboyan, dan Kapuas yang dapat dilihat pada tabel berikut.

Tabel 5. Struktur Bentuk Kata Toponimi Jalan Kota Bengkulu

\begin{tabular}{|l|l|}
\hline No. & \multicolumn{1}{|c|}{ Toponimi Nama Jalan Kota Bengkulu Bentuk Kata } \\
\hline 1 & Asahan \\
\hline 2 & Bali \\
\hline 3 & Flamboyan \\
\hline 4 & Indragiri \\
\hline 5 & Kapuas \\
\hline 6 & Fatmawati \\
\hline
\end{tabular}

\section{Struktur Bahasa Bentuk Majemuk}

Kata majemuk atau majemuk adalah proses morfemis yang menggabungkan dua morfem dasar menjadi satu kata dan tidak memungkinkan terpisah. Lebih rinci proses hasil 
penentuan kata majemuk dalam bahasa Melayu dari data toponimi jalan Kota Bengkulu dianalisis melalui empat kriteria, yaitu:

a. Bentuk merupakan gabungan dua unsur/kata,

b. Bentuk gabungan memiliki satu makna,

c. Gabungan unsur yang ada bersifat padat, bila dipisahkan atau disisipi unsur lain menjadi tidak gramatikal.

d. Komponen unsur tidak dapat dipertukarkan.

Pada sebelas struktur bahasa toponimi nama Jalan Kota Bengkulu dalam bentuk kata majemuk, yaitu: Bakti Husada, Basuki Rahmat, Batang Hari, Kebun Veteran, Raden Patah, Ratu Agung, Soekarno Hatta, Sungai Rupat, Mahakam Raya, Fatmawati, Putri Gading Cempaka, dan Ratu Agung yang keseluruhan dapat dilihat pada tabel berikut.

Tabel 6. Kata Majemuk Toponimi Jalan Kota Bengkulu

\begin{tabular}{|c|l|}
\hline No. & Toponimi Nama Jalan Kota Bengkulu Bentuk Kata Majemuk \\
\hline 1 & Bakti Husada \\
\hline 2 & Basuki Rahmat \\
\hline 3 & Batang Hari \\
\hline 4 & Kebun Veteran \\
\hline 5 & Raden Patah \\
\hline 6 & Ratu Agung \\
\hline 7 & Soekarno Hatta \\
\hline 8 & Sungai Rupat \\
\hline 9 & Mahakam Raya \\
\hline 10 & Putri Gading Cempaka \\
\hline 11 & Ratu Agung \\
\hline
\end{tabular}

Data yang ada menunjukkan kecenderungan penggunaan struktur bahasa majemuk pada toponimi jalan Kota Bengkulu. Menilik pola atau tipe dari struktur bahasa toponimi nama jalan Kota Bengkulu dapat dijelaskan bahawa penamaan (naming) pada suatu daerah memiliki makna dibalik nama satu tempat yang di dalam penamaan pasti memiliki nilainilai kehidupan atau filosofis yang menjadi ciri khas bahasa dan masyarakat daerah. Termasuk pada penamaan tempat ternyata tidak pernah lepas dari berbagai aspek atau berbagai fenomena geografi yang hadir di balik nama tempat itu, karena pemberian nama tempat biasanya berdasarkan pengalaman dan pertimbangan dari masyarakat sendiri. Pada umumnya nama geografis suatu daerah dibuat berdasarkan nama diri (proper name), nama spesifik, ekspresi suatu entitas dikenal, atau lainnya. 
Jurnal Onoma: Pendidikan, Bahasa dan Sastra

Volume 7 Nomor 1 Tahun 2021

Hasil penelitian menunjukkan bahwa pola bahasa toponimi jalan kota Bengkulu klasifikasi hasil analisis keseluruhan sebagai berikut:

Tabel 7. Pola Struktur Bahasa Toponimi Jalan Kota Bengkulu

\begin{tabular}{|l|l|c|c|c|c|c|}
\hline No. & $\begin{array}{c}\text { Toponimi Nama Jalan Kota } \\
\text { Bengkulu }\end{array}$ & \multicolumn{5}{|c|}{ Pola Penyusunan Geografis } \\
\hline & \multicolumn{1}{|c|}{ Nama } & Tempat & Bunga & Proses & Ilmu \\
\hline 1 & Asahan & & & & $\sqrt{ }$ & \\
\hline 2 & Bakti Husada & & & & & $\sqrt{ }$ \\
\hline 3 & Bali & & $\sqrt{ }$ & & & \\
\hline 4 & Basuki Rahmat & $\sqrt{ }$ & & & & \\
\hline 5 & Batang Hari & & & $\sqrt{ }$ & & \\
\hline 6 & Flamboyan & & $\sqrt{ }$ & & & \\
\hline 7 & Indragiri & & $\sqrt{ }$ & & & \\
\hline 8 & Kebun Veteran & $\sqrt{ }$ & & & & \\
\hline 9 & Raden Patah & $\sqrt{ }$ & & & & \\
\hline 10 & Ratu Agung & & $\sqrt{ }$ & & & \\
\hline 11 & Soekarno Hatta & & $\sqrt{ }$ & & \\
\hline 12 & Sungai Rupat & & $\sqrt{ }$ & & \\
\hline 13 & Mahakam Raya & $\sqrt{ }$ & & & & \\
\hline 14 & Kapuas & $\sqrt{ }$ & & & & \\
\hline 15 & Fatmawati & $\sqrt{ }$ & & & & \\
\hline 16 & Putri Gading Cempaka & & & & \\
\hline 17 & Ratu Agung & & & & \\
\hline
\end{tabular}

Pada data menunjukkan bahwa toponimi jalan Kota Bengkulu cenderung menggunakan nomina atau kata benda baik pada struktur kata atau majemuk dan memiliki kecenderungan pada pola nama yaitu pada nama diri (Basuki Rahmat, Raden Patah, Ratu Agung, Soekarno Hatta, Fatmawati, Putri Gading Cempaka, dan Ratu Agung) dan nama diri yang digunakan pada toponimi jalan Kota Bengkulu berdasarkan data diambil dari nama tokoh. Keseluruhan pola pada hasil penelitian dapat dikelompokkan menjadi lima kelompok, yaitu: 1). Nama (diri), yaitu: Basuki Rahmat, Raden Patah, Ratu Agung, Soekarno Hatta, Fatmawati, Putri Gading Cempaka, dan Ratu Agung. 2). Tempat, yaitu: Bali, Batang Hari, Indragiri, Kebun Veteran, Sungai Rupat, Mahakam Raya, dan Kapuas. 3). Bunga, yaitu: Flamboyan.4). Proses, yaitu: Asahan dan 5). Ilmu, yaitu: Bakti Husada. 
Jurnal Onoma: Pendidikan, Bahasa dan Sastra

ISSN 2443-3667 (Print)

PBSI FKIP Universitas Cokroaminoto Palopo

ISSN 2715-4564 (Online

Volume 7 Nomor 1 Tahun 2021

\section{Simpulan}

Tujuh belas toponimi nama jalan kota Bengkulu adalah: Asahan, Bakti Husada, Bali, Basuki Rahmat, Batang Hari, Flamboyan, Indragiri, Kebun Veteran, Raden Patah, Ratu Agung, Soekarno Hatta, Sungai Rupat, Mahakam Raya, Kapuas, Fatmawati, Putri Gading Cempaka, dan Ratu Agung.

Struktur bahasa bentuk toponimi nama jalan kota Bengkulu memiliki dua struktur bahasa yaitu kata dan majemuk dengan kecenderungan pada kata majemuk. Pada struktur kata dengan jumlah enam data (Asahan, Bali, Indragiri, Flamboyan, dan Kapuas) dan sebelas struktur kata majemuk (Bakti Husada, Basuki Rahmat, Batang Hari, Kebun Veteran, Raden Patah, Ratu Agung, Soekarno Hatta, Sungai Rupat, Mahakam Raya, Fatmawati, Putri Gading Cempaka, dan Ratu Agung).Terdapat kecenderungan menggunakan kata majemuk.

Pola struktur bahasa toponimi jalan kota Bengkulu dapat dikelompokkan menjadi lima kelompok, yaitu: 1). Nama bisa nama diri (Basuki Rahmat, Raden Patah, Ratu Agung, Soekarno Hatta, Fatmawati, Putri Gading Cempaka, dan Ratu Agung. 2). Tempat, yaitu: Bali, Batang Hari, Indragiri, Kebun Veteran, Sungai Rupat, Mahakam Raya, dan Kapuas.3). Bunga (Flamboyan). 4). Proses (Asahan). 5). Ilmu (Bakti Husada). Cenderung menggunakan nomina atau kata benda dengan menggunakan pola nama nama diri.

\section{Ucapan Terima Kasih}

Diucapkan terima kasih pada Universitas Muhammadiyah Bengkulu sebagai penyandang dana pada penelitian institusi.

\section{Daftar Pustaka}

Anshari, Bayu Iqbal, Moh. Dede, Rio Tirtayasa, dkk. 2017. Kajian Etnosemantik dalam Toponimi Wilayah Kabupaten dan Kota Cirebon. Prosiding Seminar Internasional Leksikologi dan Leksikografi. 64 -- 69.

Astrea, Kiki. 2017. Hipotesis Sapir-Whorf dalam Proses Toponimi Kabupaten Tuban (Kajian Antropologi Linguistik). Jurnal Bastra, Vol. 4, No. 1, 49 -- 56.

Irawan, Dicky. 2020. Analisis Semantik pada Penamaan Diri Mahasiswa di Prodi Pendidikan Jasmani Universitas Muhammadiyah Kotabumi. Edukasi Lingua Sastra. Vol. 18 (1). 86-93.

https://jurnal.umko.ac.id/index.php/elsa/article/view/223.

Djajasudarma. T. Fatimah. 2016a. Metode Penelitian Linguistik. Fakultas Ilmu Budaya Universitas Padjadjaran: Bandung.

Djajasudarma. T. Fatimah. 2016b. Sintaksis dan Semantik. Fakultas Ilmu Budaya Universitas Padjadjaran: Bandung.

Djajasudarma, T.Fatimah dan Elvi Citraresmana. 2016. Metodologi dan Strategi Penelitian Linguistik. Fakultas Ilmu Budaya Unpad: Bandung.

Kamus Besar Bahasa Indonesia (KBBI) Online. Diakses melalui https://kbbi.web.id. 
Jurnal Onoma: Pendidikan, Bahasa dan Sastra

ISSN 2443-3667 (Print)

PBSI FKIP Universitas Cokroaminoto Palopo

ISSN 2715-4564 (Online

Volume 7 Nomor 1 Tahun 2021

Kridalaksana, Harimurti. 1996. Teori Morfologi Dewasa ini: Bagian I -- Morfologi Klasik. PELBBA 11, 173 - 183.

Muhyidin, Asep. 2017. Kearifan Lokal dalam Toponimi di Kabupaten Pandeglang Provinsi Banten: Sebuah penelitian antropolinguistik. Jurnal Pendidikan Bahasa dan Sastra. Volume 17, No.2, 232 -- 240.

Munir, Mesiyarti. 2017. Jejak Indonesia dalam Penamaan Nama Tempat dan Jalan di Singapura: Sebuah Kajian Toponimi. https://linguistik.fib.ui.ac.id/. 183 --185

Rustinar, Eli. 2020. Makian Bahasa Melayu Bengkulu: Kajian Sosiopragmatik. Disertasi FIB Unpad: Bandung.

Spradley, James P. 2006. The Ethnographic Interview (Metode Etnografi). Diterjemahkan oleh Misbah Zulfa Elizabeth. Tiara Wacana: Yogyakarta.

Sugianto, Alip. 2017. Pola Nama Desa di Kabupaten Ponorogo pada Era Adipati Raden Batoro Katong (Sebuah Tinjauan Etnolinguistik). Jurnal Sosial Humaniora. Vol.10, Ed. 1, $34-46$.

Ullman, Stephen. 2012. Pengantar Semantik (Semantics, An Introduction to the Science of Meaning). Diterjemahkan oleh Sumarsono. Yogyakarta: Pustaka Pelajar.

Verhaar, J.W.M. 2006. Asas-asas Linguistik Umum. Yogyakarta: Gadjah Mada University Press. 